\title{
IMPACT OF THE GLOBAL FINANCIAL CRISIS ON BRICS AND PIIGS COUNTRIES
}

Selçuk BALI*, Erol DEMIR **

* Giresun Üniversitesi, selcuk.bali@giresun.edu.tr

** Tarım Kredi Kooperatifleri Genel Müdürlüğü E-mail: eroldemir@tarimkredi.org

Copyright (C) 2015 Selçuk BALI, Erol DEMİR. This is an open access article distributed under the Eurasian Academy of Sciences License, which permits unrestricted use, distribution, and reproduction in any medium, provided the original work is properly cited.

\begin{abstract}
This paper focuses on the Global Financial Crisis of 2007-2008 that affected various economies all around the world. The crisis started when the housing market collapsed in the United States of America. The debt crisis also played its part in the problem. the Global Financial Crisis caused many big financial institutions to collapse mos"t notably Lehman Brothers. It also caused the GDPs and economies of many countries around the world to shrink. The financial crisis was soon followed by worldwide recession. Many economies during the financial crisis needed to be bailed out. Millions of people lost their jobs worldwide. The crisis was a result of failure of the regulators and the monetary policies. PIIGS countries were hit the hardest by the financial crisis in Europe. On the other hand, BRICS countries were able to negotiate the crisis rather well due to their better policies and fast growing economies and world market share.
\end{abstract}

Keywords: American Housing Market, Global Financial Crisis, Monetary Policy, BRICS, PIIGS

JEL-Clasification: G01, G19, G39

\section{KÜRESEL FINAANSAL KRIZIIN BRICS VE PIIGS ÜLKELERINNE ETKİSI}

\section{ÖZET}

$\mathrm{Bu}$ çalışma Dünya genelindeki çeşitli ekonomiler üzerinde etkili olan 2007-2008 Küresel Finansal Krizi'ni irdelemeyi amaçlamaktadır. Kriz, Amerika Birleşik Devletleri'ndeki konut piyasası sisteminin çökmesi ile başlamış ve borç krizinde önemli bir rol oynamıştır. Küresel Finansal Kriz, Lehman Brothers gibi büyük finansal kurumların iflas etmesine yol açtı. Ek olarak kriz, Dünya çapında milli gelirlerde ve ülke ekonomilerinde daralmaya ve küçülmeye 
neden olmuştur. Krizin devamında Dünya çapında resesyon yaşanmış ve birçok ekonomi kriz boyunca kurtarılmaya ihtiyaç duymuştur. Milyonlarca insan işini kaybetmiştir. Düzenleyici otoritelerin ve para politikasının başarısızlığı krizin nedeni olarak düşünülmüştür. Finansal kriz en yoğun şekilde PIIGS olarak ifade edilen ülkelerde görülmüş; diğer yandan hızla büyüyen ekonomileri ve yükselen dünya pazar payları sayesinde BRICS olarak ifade edilen ülkeler çeşitli müzakereler yaparak krizi daha iyi yönetmeyi denemişlerdir.

Anahtar Kelimeler: Amerika Konut Piyasası, Küresel Finansal Kriz, Para Politikası, BRICS, PIIGS

\section{Introduction}

The Global Financial Crisis of 2007-08 was considered by many economic experts as being the worst financial crisis the world faced since the Great Depression of 1930s. The crisis started during the summer of 2007. This severe financial crisis caused stock markets around the world to fall dramatically. Large financial institutions collapsed and several countries and their governments had to act in order to bail out their financial systems. The severity of this crisis was so immense that even the most stable and growing economies such as the United States of America, Germany, United Kingdom, South Africa, and China felt its consequences in varying degrees (Shiller, 2008). Perhaps the most significant and well-known financial giant to fall during the crises was Lehman Brothers in September of 2008 which was the largest bankruptcy filing in the history of United States of America.

The financial crises caused heavy bankruptcy and job losses all around the world and it also contributed towards the contraction of GDPs of several countries from the West to Africa and to Central Asia and Far East (Chor and Manova, 2012: 117-133). Due to the severity of the 2007-2008 financial crises, the after effects are still felt in many economies even after so many years such as low jobs available for workers in public and private sectors; countries and states reducing their workforce significantly, governments slashing their spending, low growth rates and GDPs of several countries around the world, inflation etc. The financial crisis gave the world economies and governments an opportunity to reconsider the policies they had been adopting and the chance to avoid such a drastic situation in the future.

\section{Causes of the Crises}

There are various different theories, reasons, and suggestions by economists as to why these crises really occurred. Many experts believe that the collapse of the housing market in America was a major contributor in the generation of the crises. The huge difference between the West and East in terms of trade balances was touted as another possible reason. Risky speculation and the debt crisis that was a result of years of fiscal recklessness and loose monetary policies such as banks started lending huge amounts of money and loans to 
borrowers without considering the poor credit histories of the borrowers was a significant contributor to the crisis as well. The level of debt in the economy rose sharply. Most of these loans went towards the housing properties that shored up the housing prices sharply. A huge sum also went towards the commercial real estate. It was inevitable that once the borrowers were unable to pay their loans and debts this sector will face significant downturn and the market will implode and this is exactly what happened. The economists famously named it as the "bursting of the US housing bubble". A similar trend was also observed in UK and several other European countries (McKibbin and Stoeckel, 2010: 54-86).

Another reason for the crash of the economy and generation of the financial crisis was that the regulation authorities failed to do their jobs. They failed to keep a strict check on the dodgy and risky financial practices and the economic irregularities and imbalances at major financial institutions. When major financial institutions started going bankrupt, there was a huge panic in the economy and no one was prepared to lend anymore with the fear of losing money. Companies that depended on borrowing money to pay suppliers and workers stopped and curtailed their spending causing more panic. The regulators made several other grave mistakes that included ignoring global current-account imbalances. They also ignored the irregular practices of the institutions to lend unprecedented amount of money to be invested in the housing sectors. Similarly, in several European countries, the banks helped in creating the financial panic and crises. European countries also had internal imbalances and many European economies posted huge current account loses. These imbalances were mostly because of huge amount of money borrowed from the banks and invested in the housing market. When the housing market crashed, most of the European banks were burdened with huge amount of bad debts. However, it can be safely said that the financial crises of such magnitude can only occur because of the combination of many different factors. No one factor could have triggered such a huge collapse of financial institutions and economies all around the world (Crotty, 2009: 563-580). The financial crises were majorly generated by the improper policies and monitoring of financial institutions in the West but it affected most other economies globally as well. The effects of this financial crisis were far reaching and many economies and countries are still dealing with its after effects.

\section{Macro and Micro Level Factors}

There were significant macro and micro level factors that greatly contributed towards the global financial crises in 2007-08. Monetary policy was a significant contributor factor in the development of the crises. There were two main factors involved in the monetary policy. The cost of wholesale funding was very low for intermediaries such as banks. This encouraged them to take unnecessary risks by lending huge amounts of money to borrowers without proper monitoring. The banks in this way took credit and liquidity risks. Secondly, most of this borrowed money was invested in the housing markets. Supply and demand for mortgages rose and it caused the prices to rise in the housing sector. Many economists believed that the federal bank kept the rates too low for a long period and it did not reconsider its policy in time to avoid developing a financial crisis. Global imbalances and a low interest rate were two major factors in the development of such a situation. Capital inflows were also touted as a 
major macroeconomic factor. According to many observers and economists, governments failed to monitor and regulate huge amounts of capital inflows prior to the crisis that was a negligent act on the part of the regulators. Failure to do so resulted in the build up to the financial crisis. The significant and sharp increase in the supply and demand of loans and debts also played a major part. When banks grant loans, they generate new money in the market. The elasticity between lending and low interest rates also proved critical. Due to low interest rates and no signs from the government of increasing them in the near future, the demand for loans increased in the West that created more risks in relation to credit and liquidity (Schwartz, 2012: 35-58). The balance of payments for many western countries was also showing signs of a decline. The governments and regulators failed to keep a check on the reasons and causes of such high investments in the housing sector. Out of the total debts borrowed in the last 5 years prior to the Global Financial Crisis occurred; around $62 \%$ was spent on the housing and commercial real estate sector that drove its value up significantly. Once this housing bubble burst in the United States of America and Europe, the housing market came crashing down and caused huge losses to financial institutions such as Lehman Brothers who had significantly invested a huge amount in the risky areas totaling up to 1.7 billion US Dollars (Hardaway, 2009: 33).

\section{Impact on BRICS Countries}

BRICS is the abbreviation for Brazil, Russia, India, China, and South Africa. The members of BRICS group are developing economies that are growing at a tremendous rate. These countries also have significant importance in their region and in global matters. Their significance can also be judged by the fact that these five countries hold almost $40 \%$ of the world population. During the 2007-08 global financial crisis BRICS had only 4 members. South Africa joined the group in 2010. The financial crisis affected the BRICS members as well. The growth of BRIC countries slowed down due to recession in the other parts of the world. However, their strong foreign exchange reserves as well as growing domestic demand allowed them to withstand the financial crises. Many economists and experts believe that BRICS have come out of the crises rather well (Flanders, 2011). During the financial crises, countries in the group faced varying degree of difficulties. China performed remarkably well during the crisis. Its GDP growth during the peak of financial crisis in 2007-2010 was recorded at $14.2 \%, 9.6 \%$ and $9.2 \%$ respectively. In 2010, its GDP growth rose to a remarkable $10.3 \%$. Similarly, India also performed well in terms of GDP growth during the financial crises. In the four years 2007-2010, it recorded a GDP growth of $9.9 \%, 6.2 \%, 6.8 \%$, and a remarkable $10.4 \%$. Both these countries and their economies withstood the severe financial crises that grappled the other world economies. They were able to negotiate the financial crises rather well due to a number of factors. They have the two largest populations in the world. Their domestic production and demand kept increasing. Secondly, prior to the crisis, their economies were doing well for a number of years that helped them build up significant foreign reserves. On the other hand, Brazil, Russia, and South Africa faced difficulties during the same period. The GDP of Brazil was recorded at $6.1 \%$ in 2007 that dropped to $5.2 \%$ in 2008 and then to negative $0.3 \%$ in 2009 . However, in 2010 it recorded an impressive growth 
of $7.5 \%$. Russia was the country among the BRICS that was affected the most during the financial crisis. Its GDP growth rate in 2007 was recorded at $8.5 \%$ which dropped to $5.2 \%$ in 2008 and then to a very unfavorable and negative $7.8 \%$ in 2009. However, in 2010 it managed to grow at 4\%. The years between 2007 and 2010 were the peak years of the global crisis after which some economies started to regain their confidence back. South Africa recorded GDP growth rate of 5.5\% and 3.6\% in 2007 and 2008 respectively. In 2009, its growth rate was a negative $1.5 \%$. In 2010 though, it managed to grow at a rate of 3.1\% (Bianconi et.al, 2013: 76-109). From 2010-2014, Brazil, Russia, India, China and South Africa recorded an average economic growth rate of $6.3 \%, 5.5 \%, 7.7 \%, 9.8 \%$, and $4.5 \%$ respectively.

The unemployment rates in India during the financial crisis averaged $8.9 \%$. In China, the average unemployment rate was $4.6 \%$. Brazil and Russia recorded unemployment rates of $8 \%$ and $7.2 \%$ respectively. South Africa's unemployment rate during the years 2007-2010 averaged a staggering $23.7 \%$ that was on the higher side. The BRICS countries dealt with the unemployment problem fairly well with the exception of South Africa who had an abnormally high unemployment rate. In case of inflation rates during the financial crises, China and Brazil recorded the lowest inflation rates at 3.8\% and $4.8 \%$ respectively. India and South Africa's inflation rate was a modest $7.5 \%$ and $7.3 \%$. However, Russia had the highest inflation rate among the BRICS countries at $10.5 \%$ during the global crisis. It is evident from the data that among all the BRICS countries, Russia was hit the hardest due to the financial crisis. This is because most of Russia's exports and trade consists of oil, gas, and other energy resources. During and after the crisis, the consumption and utilization of energy decreased significantly, which affected Russia and its economy. During the financial crisis, the exports and imports of BRICS showed a positive movement. The total exports were 2.7 trillion Dollars, a 20\% increase than 2007 (Holtbrugge and Kreppel, 2012: 4-30). China and India were the two better performers who absorbed much of the pressure on their economy rather well and performed well during the tough times that encountered most of the economies worldwide. None of these BRICS countries needed a bailout plan from their governments or from any other financial institution that shows they performed quite well during the period and absorbed the crisis well.

\section{Impact on PIIGS Countries}

PIIGS is the abbreviation for Portugal, Ireland, Italy, Greece, and Spain. These are the economies based in of Europe. These countries were hit the hardest by the Global Financial Crisis in Europe. Because of the fact that they used Euro as the uniform single currency, they were unable to adopt an independent monetary policy to tackle the crisis on their own. During the financial crisis, European Union approved 760 billion Euro package to help and bail out these economies. The financial difficulties faced by these nations gave rise to the debate about having a single currency for the whole European Union. All these five PIIGS countries faced severe economic downturn. Economists and experts believe that these five nations were the most affected nations in Europe (Economist, 2011). During the financial crisis, these economies experienced several indicators of a weak and fragile economic system. The 
average unemployment rate in Portugal rose to $9 \%$ while Italy faced an unemployment rate of $7.3 \%$. Ireland and Greece experienced their highest unemployment rate during the financial crisis and recorded an unemployment rate of $9.1 \%$ and $9.4 \%$ respectively. Spain was hit the hardest. It had an unemployment rate of $15.1 \%$ which was abnormally high. Similarly, these nations also faced a significant decline in their economic growth rate. Spain recorded a GDP growth rate of $3.8 \%$ in 2007 which fell to only $1.2 \%$ in the following year. For the next two years 2009 and 2010, it performed extremely poorly and recorded a negative $3.7 \%$ and negative $0.1 \%$. Spain failed to withstand the financial crisis which resulted in Spain joining the European sovereign debt crisis because it failed to bail out its financial sector. Portugal also faced similar difficulties. The debts in its economy had increased significantly as compared to the GDP of the economy. In 2010, its unemployment rate increased to $11 \%$ which was its highest recorded in over 20 years. Portugal had already joined the European Sovereign debt crisis because of its failure to bail out its financial system and the bursting of the housing market bubble. Portugal's economic growth rate was already low at $1.8 \%$ in 2007 which then went negative for the next two years and was recorded at $-0.1 \%$ and $-2.6 \%$. In 2010 it performed comparatively better and achieved a low GDP growth of $1.2 \%$.

Greece was one of the fastest growing economies in Europe before the financial crisis occurred. Greece's main business activities were shipping and tourism. These industries were badly affected during the crisis because of their vulnerable business cycles. Greece had to be bailed out several times by the IMF, EU and World Bank because of the government's failure to spend anymore amount to bail out its financial system. Greece's economy and economic growth rates took a hit and were recorded at $4 \%$ and $2.9 \%$ in 2007 and 2009 respectively. In 2009 and 2010, it performed even more poorly and was recorded $-2 \%$ and $-4.5 \%$. Greece is still facing financial difficulties in respect of its debts and is actively seeking another bailout package from the monetary institutions. Similarly, Ireland also faced severe financial downturn. Ireland's GDP economic growth took a huge setback during the financial crisis (Pitelis, 2012). From a healthy growth of $6 \%$ in 2007, it sharply fell to $-3 \%$ the following year. Ireland failed to recover in 2009 as well performed even more poorly depicted by its shrinking economy. It recorded $-7.6 \%$ in 2009. In 2010, its economy performed comparatively better but still recorded $-1 \%$. It can be argued that Ireland was the country most affected among the PIIGS group. Its economy shrunk for the first time in 2007 since nearly 28 years. Among all the countries in Europe, Ireland was the first country to experience recession followed by a huge unemployment rate.

Italy and its financial institutions especially banks suffered little during the initial stage of the financial crisis. When Lehman Brothers collapsed, it brought huge amount of uncertainty and mistrust in the Italian banking and financial sectors. Banks refused to lend money to each other because of liquidity issues and the uncertainty about the credit risk of the borrowers. Due to lack of money and credit available, Italy suffered and faced crisis. Italian stock markets shrunk to an all time low. The assets started devaluing and investors started losing trust on the markets. Due to unavailability of credit to clients, financial activities started to reduce significantly causing many companies to close and large number of workforce to be 
laid off (Di Qurico, 2010: 3-19). Italy's GDP growth rate was 1.4\% in 2007 which declined to $-1 \%$ in 2008 and $-5.1 \%$ in 2009. However, in 2010 it performed relatively better and recorded a growth rate of $1.3 \%$. Surprisingly, the average inflation rates in the PIIGS countries from 2007-2010 remained very low as compared to the BRICS countries. Portugal, Ireland, Italy, Greece and Spain recorded very low inflation rates of $1.3 \%, 0.7 \%, 1.9 \%, 3.2 \%$, and $2 \%$ respectively. The PIIGS were hit the hardest in the financial crisis after the United States of America. Their fragile economies got exposed in the wake of the financiall difficulties. It also demonstrated the fact that the governments were simply not prepared for such a financial crisis and had no comprehensive monetary and fiscal policies to regulate the financial sectors and ensure their smooth running.

During and after the Global Financial Crisis, it was evident that the BRICS countries survived and coped with it rather well. The factors which helped the BRICS included their large populations, constantly fast growing economies, large consumer demand, and their significance in their respective regions both strategically and politically. Prior to the crisis, these nations were already performing well and had huge amounts of foreign reserves. Secondly, most of the BRICS countries were not involved in the housing markets and real estate like the United States of America and Europe. Once this housing bubble as economist often call it busted, the economies of the west came crashing down and many of them had to be bailed out by their respective governments and institutions such as IMF, EU etc. PIIGS countries on the other hand were responsible for constantly neglecting the alarming factors such as low interest rates on borrowings, huge amount of borrowing and investment in the real estate and housing sectors, financial institutions lending huge amount of money to risky clients, regulators failure to monitor and regulate the sector etc. The total population of PIIGS is also very low as compared to the world in general and BRICS in particular. The bulk of their trade imports and exports were mostly concentrated towards each other and other European nations. Once the financial crisis struck, all economies of Europe came crashing down together. Most of the PIIGS countries needed financial bailout packages to recover. Many of them have not fully recovered yet even after many years especially Greece and Spain (Cukierman, 2013: 373-384).

\section{Conclusion}

the Global Financial Crisis of 2007-2008 was one of the most difficult periods financially for many economies around the world especially the west. It caused several small and big financial institutions to close down, layoffs of employees all around the globe, crashing and volatile movements of the stock markets and social unrest and political unrest. Many large and small economies are still coming to terms with the global crisis. Many countries are still facing financial problems, liquidity problems, and lack of investors trust. The crisis also affected lives of millions of people and workers all around the world. It also gave rise to recession that slowed down the world economic activities even further. Although the financial institutions can provide stability and the much needed liquidity to the economy for the smooth running of affairs, if it is not regulated, managed and the risks retained, it can create severe 
difficulties for the economies as witnessed in the form of global crisis. However, the financial crisis provided the world with a much needed awakening as well. It is because of the financial crisis the world economies and government seriously started to regulate and monitor the activities of the financial sectors. It also gave the opportunity to introduce new and stricter policies by the governments to avoid such crisis in the future. It is very important that the world realize the importance of managing their financial institutions well to avoid any similar circumstances in the future. 


\section{REFERENCES}

- $\quad$ BIANCONI, M., YOSHINO, J. A., \& de SOUSA, M.O.M. (2013). "BRIC and the US Financial Crisis: An Empirical Investigation of Stock and Bond Markets", Emerging Markets Review, 14, pp. 76-109.

- CHOR, D., \& MANOVA, K. (2012). "Off the Cliff and Back? Credit Conditions and International Trade During the Global Financial Crisis", Journal of International Economics, 87(1), pp. 117-133.

- CROTTY, J. (2009). "Structural Causes of the Global Financial Crisis: A Critical Assessment of the "New Financial Architecture", Cambridge Journal of Economics, 33(4), pp. 563-580.

- CUKIERMAN, A. (2013). "Monetary Policy and Institutions Biefore, During, and After the Global Financial Crisis", Journal of Financial Stability, 9(3), pp. 373-384.

- Di QUIRICO, R. (2010). "Italy and the Global Economic Crisis", Bulletin of Italian Politics, 2(2), pp. 3-19.

- Economist Online, the (2011, January 4), "Grounded PIIGS, GDP Forecasts". http://www.economist.com/blogs/dailychart/2011/01/gdp_forecasts. ET. 19 Ekim 2014.

- FLANDERS, S. (2011). "the Global Financial Crisis and the BRICs", November 21, 2011. http://www.bbc.com/news/business-15817660. ET. 08 Ekim 2014.

- HARDAWAY, R. (2009). "Great American Housing Bubble: Re-Examining Cause and Effect", the U. Dayton L. Rev., 35, p. 33.

- HOLTBRUGGE, D., \& KREPPEL, H. (2012). "Determinants of Outward Foreign Direct Investment from BRIC Countries: An Explorative Study", International Journal of Emerging Markets, 7(1), pp. 4-30.

- McKIBBIN, W.J., \& STOECKEL, A. (2010). "the Global Financial Crisis: Causes and Consequences", Asian Economic Papers, 9(1), pp. 54-86.

- PITELIS, C.N. (2012). "On PIIGs, GAFFs, and BRICs: An Insider-Outsider's Perspective on Structural and Institutional Foundations of the Greek Crisis", Contributions to Political Economy, bzs002. http://www.econ.uoa.gr/uploads/media/ECON5_2012_ON_PIIGS_GAFFS AND_BRICS_Pitelis.pdf ET. 19 Ekim 2014.

- SCHWARTZ, H. (2012). "Housing, the Welfare State, and the Global Financial Crisis What is the Connection?", Politics \& Society, 40(1), pp. 35-58.

- SHILlER, R.J. (2008). the Subprime Solution: How Today's Global Financial Crisis Happened, and What to Do about it, Princeton University Press, Princeton, New Jersey. 